\title{
The Means-End Approach to Understanding Customer Values of a On-Line Newspaper
}

\author{
André Luiz M. de Souza Leão \\ E-mail address: aleao21@yahoo.com.br \\ Grupo de Estudos e Pesquisas em Tecnologia, Estudos Culturais e Consumo - Universidade Federal de Pernambuco \\ Mestrado Profissional em Gestão Empresarial - Faculdade Boa Viagem \\ Recife, PE, Brazil

\section{Sérgio C. Benício de Mello*} \\ E-mail address: sergio.benicio@gmail.com / scbm@elogica.com.br \\ Grupo de Estudos e Pesquisas em Tecnologia, Estudos Culturais e Consumo - Universidade Federal de Pernambuco \\ Recife, PE, Brazil
}

\begin{abstract}
Customer value is understood as one of the constructs that best explains consumer decision making. Its proposal is to understand how consumers translate product or service characteristics and consequences of use into personal self-relevant values. The means-end theory is a way of systematically thinking in this hierarchical representation. The most commonly used method to achieve means-end chains is laddering. This theory and method were used to understand customer values of an important on-line Brazilian newspaper, which is an innovative approach, since on-line laddering is uncommon. The findings indicate that values related to goals of a personal nature are the most important ones. However, other values indicate the increase of the public man pointing to an alternative vision of what is commonly thought of as the contemporary isolated and selfish human. Academic research could benefit from a broader understanding and use of the means-end theory and laddering on the Web. Future research for managerial practices is warranted in areas such as segmentation, satisfaction measuring and customer value reevaluation, in addition to copy tests.
\end{abstract}

Key words: customer value research; means-end theory; laddering; on-line consumption.

Received 13 June 2005; received in revised form 13 June 2006.

Copyright (C) 2007 Brazilian Administration Review. All rights reserved, including rights for translation. Parts of this work may be quoted without prior knowledge on the condition that the source is identified.

\footnotetext{
* Corresponding author: Sérgio C. Benício de Mello

Universidade Federal de Pernambuco, Departamento de Ciências Administrativas, Núcleo MTN/PROPAD/UFPE, $1^{\circ}$ andar, Sala D-30, Av. dos Economistas s/n - CCSA, Recife/PE, 50670-901, Brazil.
} 


\section{INTRODUCTION}

The $20^{\text {th }}$ Century was probably the most packed with social, cultural and - above all - technological change and innovation. In this sense, its last years brought on what we could call a revolution: the Internet, a mixture of means of communication and space for interpersonal interaction, business and shopping. To the field of marketing, one aspect seems particularly important in this context: How will the behavior of this new consumer be processed, this online shopper? Might it be that the characteristics of access to news, use of services and purchasing in the physical world will carry over to cyberspace (as the virtual space of the Internet is known)? Or, rather, will the interaction within a new medium affect people's buying behavior? Or, even if that is not the case, will the possibilities the medium offers influence the behavior process? One thing is for certain, there seems to be great scope for research within this area.

This study aims to take a step in that direction, among the many others still to come. In order to do so, the focus falls upon a fundamental aspect of behavior: human values. The literature relates value to various other constructs understood as guides to behavior, such as attitude, judgment of preference and choice. The study of values seems to be of key importance in this seminal phase of research into online consumer behavior, as it is the basis for one of the first steps in this process: to know and understand this consumer.

The fact that customer value has gained growing importance in marketing literature is nothing new. Its application has been related to product and brand strategies (e.g., differentiation, positioning) achieving a competitive advantage over competitors (Dibley \& Baker, 2001; Gutman, 1981; Reynolds \& Gutman, 1988; Vriens \& Hofstede, 2000; Woodruff, Schumann, \& Gardial, 1993; Woodruff \& Gardial, 1996; Woodruff, 1997); as a means of setting segmentation strategies (Gengler \& Reynolds, 1995; Kamakura \& Mazzon, 1991; Kamakura \& Novak, 1992; Lin, 2002; Prakash, 1986; Reynolds \& Gutman, 1988; Vriens \& Hofstede, 2000); as a powerful tool in creating communications strategies (Prakash, 1986; Reynolds \& Gutman, 1984, 1988; Reynolds \& Whitlark, 1995; Vriens \& Hofstede, 2000; Woodruff \& Gardial, 1996); and as a construct with a strong explanation of consumer behavior and even determinant of attitudes (Dibley \& Baker, 2001; Gengler \& Reynolds, 1995; Grunert, Sorensen, Johansen, \& Nielsen, 1995; Gutman, 1981; Perkins \& Reynolds, 1988).

The central proposal of the construct is that consumers translate product or service attributes into benefits (or consequences of use) and then into their own value orientation, in a hierarchical representation (Gengler \& Reynolds, 1995). In other words, the consumers themselves value the recognition of their personal values when using a product or service (Woodruff \& Gardial, 1996). Thus, values are beliefs that guide actions and judgments through specific objectives and situations, beyond immediate objectives to deeper end-states of existence (Olver \& Mooradian, 2003; Rokeach, 1968). The means-end theory is a way of systematically conceptualizing this hierarchical representation, with the laddering technique as the most commonly used method to achieve it (Gengler \& Reynolds, 1995; Grunert et al., 1995; Woodruff \& Gardial, 1996).

The purpose of this research is to understand the customer values of an important on-line Brazilian newspaper through means-end chains and laddering. Furthermore, it puts forward two peculiar aspects. The first is related to the fact that this study has been carried out over the Internet, which is pioneering in studies involving laddering techniques. In order to do so, some adaptations were made in accordance with the original technique and validated with the achievement of results relative to the means-end chains theory. Hence, such adaptations are presented and discussed. The second peculiar aspect is the emphasis given to data analysis, above all in relation to the construction of a cognitive map or the users through the so-called hierarchical value map. This peculiarity of the study satisfies both validity and reliability in qualitative research criteria, providing a rich and detailed description of its results (Merrian, 1998), as well as offering the reader an understanding of such mechanisms in a detailed manner, something which we do not commonly see in publications related to this technique, in which many aspects of the analysis are not presented in a clear way - as 
evidenced in our text - forcing Valette-Florence and Rapacchi (1991) to suggest that it is "a manual path derivation which can lead to various omissions or errors” (p. 32).

Its relevance is the contribution in using the means-end theory in Brazil, where it was applied for the first time. Moreover, the environment where the data collection occurred was the Internet - one of the first attempts of on-line laddering, as well as the detailed description of its analytic process, which helps contribute to an easier understanding by those interested in carrying out research of this kind. Finally, the research utilized one of the largest samples in means-end research known.

The paper opens by reviewing the theoretical foundations of value construct and then of the meansend theory. Subsequently, the use of laddering in this research is described, and a hierarchical map is presented. Finally, conclusions are drawn and future research considered.

\section{The Concept of Value in Social Psychology}

The origins of the concept of value lie in social psychology, in which Milton Rokeach $(1968,1973$, 1979) defined value as a long lasting belief which guides actions and judgments through specific objectives and situations apart from the immediate objectives, towards end-states of a deeper existence - the belief that a certain behavior or an end-state of existence is personally or socially preferable to an opposite end-state of existence; something more fundamental than attitude, oftentimes supporting it.

From this perspective it is assumed that the values are culturally absorbed in order to create and use conditions of morality and competence, to create social interaction and to support the rationalization of beliefs, attitudes and behaviors. Once internalized the values become - whether consciously or not - a pattern of criteria which guides action and develops and sustains attitudes towards objects and situations. It is in this respect that this can be understood as a synthesis between what would be a sociological vision and a psychological one. Even if the values "dwell" within people, they are forged socially. Therefore, values are as central to the lives of individuals as to society as a whole.

In fact, values can be classified into two categories: personal (individual) and social (institutional, cultural, organizational). For example, the attribution made about someone being a helpful person can also fit into organizations. Nonetheless, they are like two sides of the same coin, each socially shared. Whereas the former are presented as cognitive representations of institutional objectives, the latter show themselves to be cognitive representations of personal needs and the means to fulfill them. In other words, social values are shared beliefs that characterize a group of people and define the acceptable normal behavior to a society or group; personal values on the other hand, define the acceptable normal behavior of an individual.

Rokeach also determines that values develop along two dimensions: (1) the types of personal objectives that one might have; and (2) the type of behavior that one might use as a way to reach these goals. Therefore, he proposes that values are divided into terminal and instrumental. These values complement each other, specifying a general lifetime goal and identifying acceptable behaviors that can be used to reach that objective. For example, the terminal value "equality" could have as a means the instrumental value "helpfulness"; in other words, to be helpful can be an identifying value of someone who strives for equality. In fact, the terminal values are a representation of preference of final state of existence, while the instrumental represent the kinds of preferential behavior to reach the terminal ones. These instrumental values, in fact, have as much of a moral as a competence nature. Thus, once violated, they trigger crises of conscience or feelings of guilt in the individual - for having committed a mistake - or lead to feelings of shame, linked to personal inadequacy. 


\section{MEANS-END THEORY}

The means-end theory sustains that the way consumers relate to products can be represented by a hierarchical model of three interconnected levels: product attributes, consequences of use and personal values (Copetti, 2005; Dibley \& Baker, 2001; Grunert et al., 1995; Kaminski \& Prado, 2005; Leão \& Mello, 2001, 2002, 2003; Lin, 2002, Reynolds \& Gutman, 1984; Perkins \& Reynolds, 1988; Reynolds \& Perkins, 1987; Serralvo \& Ignácio, 2005; Valette-Florence \& Rapacchi, 1991; Veludo-de-Oliveira \& Ikeda, 2004; Vriens \& Hofstede, 2000; Woodruff \& Gardial, 1996). The theory approach is based on the assumption that consumers see products as a means to important ends and try to explain how the selection of a product or service facilitates the achievement of desired end-states (Gutman, 1981; Leão \& Mello, 2001, 2002, 2003; Mulvey, Olson, Celsi, \& Walker, 1994). Level is a term used to represent the hierarchical categorization of the contents of associations, ranging from product or service characteristics to personal values (Reynolds \& Gutman, 1984). Thus, the higher the hierarchical level, the more the level of abstraction grows (Woodruff \& Gardial, 1996). This aspect of association of the means-end model makes possible the analysis and interpretation of how consumers perceive products or services as self-relevant (Grunert et al., 1995; Walker \& Olson, 1991) and how these go beyond functional properties to having meaning in the consumer's life (Perkins \& Reynolds, 1988).

The means-end chain model developed by Gutman (1982) sustains the supposition that values are dominant factors in the pattern of consumer purchase; that these consider products or services based on the function of satisfying values; that all actions have consequences (desired or not); and, finally, that there is a connection between consequences and product or service attributes. The central aspects of the model are consumer decision-making that produce desired consequences (positive) and minimize undesired ones (negative).

The model is based on the attribute-consequence-value (A-C-V) sequence that forms a means-end chain (Gengler, Mulvey, \& Oglethorpe, 1999; Leão \& Mello, 2001, 2002, 2003; Prakash, 1986; Valette-Florence \& Rapacchi, 1991; Vriens \& Hofstede, 2000). A means-end chain, therefore, is a structure that connects product or service attributes to consequences produced by these and the latter to values (Mulvey et al., 1994; Reynolds \& Gutman, 1988). For example, the attribute quality can lead to a consequence of optimizing time, which can also lead to the value security.

In order to preserve certain peculiarities of the sequence, as well as some of their own relationships, the A-C-V model can be amplified. While the basic A-C-V divides the means-end hierarchy in just three levels, its amplified version uses six, dividing attributes into concrete (CA) and abstract (AA); consequences in functional (FC) and psychological (PC); values in instrumental (IV) and terminal (TV) (Grunert et al., 1995; Reynolds \& Gutman, 1984; Walker \& Olson, 1991), as shown in Figure 1.

Figure 1: Customer Value Hierarchy (A-C-V Model Amplified)

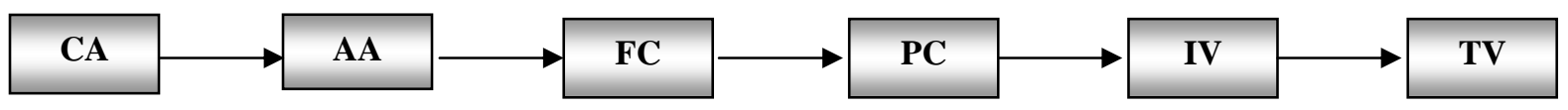




\section{MetHOdOLOGICAL IsSUES}

This research is a particular type of case study characterized as positive-micror-profit (Hunt, 1991). It was conducted amongst users of an important on-line Brazilian newspaper. It is worth highlighting here that as our focus in the study was on online consumers, the choice of the product of consumption could have been any given one offered over the Internet. The selection of the newspaper in question came about due to three aspects: 1) at the time in which the study was realized, e-commerce was still relatively unknown and had little representability within online business, as content-oriented sites were the most sought after; 2) it is the electronic version of the leading newspaper in its state, part of a system of media which includes radio stations (AM and FM), TV channels and an Internet portal; 3) the newspaper was very open to recommending the study to its users, which was of key importance since it would be necessary to reach the clients through an initiative such as this one, keeping in mind that the study itself was Internet-based.

Laddering, as anticipated, is the most popular method used to achieve the means-end chains (Gengler \& Reynolds, 1995; Grunert et al., 1995; Leão \& Mello, 2001, 2002, 2003; Woodruff \& Gardial, 1996). It refers to an in-depth, individual interview, used to develop an understanding of how consumers translate product or service attributes into meaningful associations with themselves (Dibley \& Baker, 2001; Gutman, 1982; Reynolds \& Gutman, 1988; Reynolds \& Whitlark, 1995). During interviews, a series of questions such as Why is this important to you? starting with product or service attributes, was used. It aimed to make possible the achievement of a higher degree of abstraction by the interviewees, on each new question, identifying existing connections between attributes, consequences and values (Gengler et al., 1999; Gengler \& Reynolds, 1995; Leão \& Mello, 2001, 2002, 2003; Perkins \& Reynolds, 1988; Reynolds \& Perkins, 1987; Reynolds \& Whitlark, 1995; Valette-Florence \& Rapacchi, 1991; Vriens \& Hofstede, 2000; Woodruff \& Gardial, 1996), understanding the consumers' knowledge of a product or brand and how these connections influence decisions regarding choice and purchase (Dibley \& Baker, 2001; Gengler \& Reynolds, 1995).

The construction of an A-C-V sequence (i.e., ladder), serves to identify the consumer perception of how these three levels relate. The method proposes to identify ladders from each respondent, quantifying the elements and their relationships, in order to build these connections graphically for each sample. It allows for an interpretation of the values of a group of consumers and which connections (i.e., chains) are the strongest and, therefore, most important for the comprehension of the phenomenon and decision-making related to its application (Reynolds \& Gutman, 1988).

\section{Data Collection}

The data collection was carried out over 75 days, reported in 2001. A group of users who had previously participated in a survey promoted by the newspaper in question and had made themselves available for further inquiry was considered. Two hundred and fifty were invited in all. A significant amount of them (194) agreed to participate in this survey. Of these, 98 remained in the interview process. A representative amount (70) arrived at the formal end of the data collection (the thank you message, indicating that the interview has ended satisfactorily). Of the remaining 28 respondents, one part dropped out at a late stage of the interview process, blaming lack of time or uneasiness with the method used, while others simply no longer replied.

The interview validation criteria, however, were not restricted to the finished interviews. Some of these were not considered valid because they did not propitiate appropriate information for ladder building. In these cases, following countless trials to unblock the respondent, the researcher simply ended the interview, also with a thank you note. On the other hand, there were some interviews which, although lacking the closure of a formal ending, were classified as valid. This occurred because they developed some sound ladders. In these cases, the data that generated these ladders were considered 
valid. It is important to point out as a justification for this decision that, even for the finished interviews, many of the attributes did not evolve in the hierarchy that propitiated the concentration on those that were actually showing results.

Overall, 78 valid interviews out of 98 were considered for analysis, a highly significant number, especially considering the peculiarities of the method and the data collection mode itself. According to Reynolds and Gutman (1988), one fourth of the total number of interviews does not develop ladders and are excluded from further analysis. The number is significant when considering the average amount of interviews conducted on this kind of research, which can vary from 30 to 40, mainly when it is proven that the data have served their purpose with a little more than thirty interviewees.

We concede, however, a limitation on the research concerning the selection of the respondents. The fact that these users have already shown interest in taking part in the newspaper survey might indicate their previous availability and willingness to participate in many others, which might have contributed to the significant amount of interviewees that reached the final stages of the interviews. Such a decision was necessary due to the lack of knowledge of the scope of the users of the service.

\section{Adaptations Made to the Technique for Online Purposes}

As the data collection was conducted over the Internet, an adaptation had to be made: although performed by a series of e-mails (non-personal), the interviews were individual, in which the researcher sent out a new question for each answer received. The process ended when all necessary data was available.

Due to this research being carried out over the Internet, an adaptation had to be made: the interview was individual but realized through a series of (non-personal) email exchanges, in which the researcher would send a new question for each answer. The exchanges would end when the necessary data were obtained. This decision was due to two key factors: 1 ) the fact that the online newspaper did not personally know its users would make personal access to them difficult; 2) since it was an online service, the use of the very medium on which it is utilized seemed a better option for data collection. Furthermore, email can be answered by the interviewee at the site which bests suits him or her - whether at work or home - which is a great facilitator, since it avoids the need to arrange times to interview.

This technique is usually utilized for studies of classes of products, in order to distinguish brands of products in a given glass. In other words, the consumer is requested, by comparing two brands of the same kind of product, to identify the main characteristics (attributes) of his or her favorite (Gengler \& Reynolds, 1995; Mason, 1995; Reynolds \& Gutman, 1988; Valette-Florence \& Rapacchi, 1991; Woodruff \& Gardial, 1996). The study did not have the aim of being one about the online newspaper segment, nor of comparing the newspaper used for research purposes with its competitors, but rather one to better understand its users. Therefore, it was decided that the interviewee should be asked to identify the main characteristics of the very online newspaper in question. In this sense, Peter and Olson (1999) indicate as a pre-laddering phase the identification of the attributes of a product that is more important to the consumer when he or she makes a buying decision. This identification does not need to be via a choice between brands, but rather as a justification for the consumption of a given brand or product. Bearing in mind the fact that all interviewees are users of the researched online newspaper, they already would have opted for this product.

For this first step in the interview process, that of having the respondent identify the principle attributes of a product, Reynolds and Gutman (1988) recommend three ways of obtaining the result. The first, called choice of three, proposes three different brands of a given product to the respondent and asks him to think of which points of the three are the brands are the same and which are different; the second way, called difference of consumption preference, asks the respondent 
simply to point out way a given brand is preferable to the others, and the indicated characteristics are then considered attributes; a third way is called differences of occasion, in which the respondent is presented with a consumption context and asked to describe the characteristics of this consumption.

It may be said that the technique utilized in this study was closest to the second aforementioned method. Merely closest because - coherently with the decision not to analyze the kind of products or compare product preferences - this was the first adaptation made for the interview. The respondents were invited to point out the main characteristics that made them opt for the online newspaper in the study, without asking them to compare that decision with another. In this way, the first question in the interview was as follows:

'In your opinion, which are the most important characteristics of... (the online newspaper studied)? Those that are crucial to your decision to use the service, why are they so?'

Once the characteristics were identified, the interview becomes completely customized, being considered moderately structured solely for always having in mind the basic question of why is this important to you?. As mentioned previously, Reynolds and Gutman (1988) point out that two problems can surface during an interview. The first is when a respondent does not know how to answer a question. This happens due to some respondents' never having thought of a given circumstance and not being able to abstract to the point of being able to articulate the reason for the importance. The second problem is when the questions become more personal as the dynamic of the interview process evolves, causing negative reactions every time the question why is this important tends to lead the respondent over and above his or her levels of abstraction. This reaction can occur with the respondent redefining his or her answers at a level equal to or even below that which (s)he was before, simply saying I don't know, becoming silent or using arguments that make him or her go around in circles, never really satisfactorily answering the question. Aside from these, Woodruff and Gardial (1996) cite two other existing difficulties: the use of repeated questions can cause the interviewee to have the impression that they are very obvious, and, secondly, they can leave him or her fatigued.

In terms of the problems identified by Woodruff and Gardial (1996), the authors do not recommend any solutions to resolve them. However, there are some techniques, outlined below (Mason, 1995; Reynolds \& Gutman, 1988), suggested in order to deal with the remaining problems identified:

Negative laddering - In this technique, the respondent is asked why he would not act in a given fashion or why he would not like to feel a certain way. This technique is very relevant when the interviewee cannot explain why he does the things he does.

Situational context - Another way is to re-ask the question within a specific context regarding the use of a product or service. The respondents usually make better associations when they think of a real-life situation.

Contextualization of a third person - In this technique, the interviewee is asked whether he believes that other people would feel the same way in similar circumstances when that subject cannot articulate a response. This technique is used to make him feel more at ease to convey his opinions.

Return to a topic at another time during the interview - This is the most commonly used method: when a given topic is not being well received or understood by the interviewee, one should stop momentarily with the line of questioning in order to take it up again at a later time within the same interview. This avoids making the subject feel pressured.

Revelation of a personal fact - One way to establish rapport with the interviewee is to reveal to him or her some sort of personal (made up) fact so that he or she feels less inhibited. This method is, however, considered by authors to be the most dangerous. 
Loss of a characteristic - Another technique that is used in order to avoid blockages by the interview subjects is to have the interviewee imagine a product or service without a given characteristic.

Contract with age regression - Another method is having the subject go back in time, suggesting that he compare his current habits with those of the past.

Redirecting techniques - There are still two other ways of stimulating a response, called redirecting techniques: the first way is to be silent so that the respondent continues to reflect on his answer until getting to an answer; the second is to do a kind of communication check, repeating interviewee's answer or asking what the subject meant by it.

Indeed, during data collection, such problems occurred various times and, despite the interview being carried out via text, some of the techniques were adaptable. Below are some examples of how the problems were resolved during the interviews:

Utilization of a situational context:

'What would happen if you were to become unemployed?' (do not consider what you would do but what that represents to you).

Use of a third person:

- 'What do you think Internet users feel when they cannot access a certain site for not being subscribers?'

Returning to a point at another time during the interview:

. 'In your first email, you had mentioned as a characteristic...'

Loss of a characteristic:

. 'What would happen is there were no Internet and you, due to a lack of time...'

Communication check:

. 'In order for me to understand your point better, how would you exemplify 'somewhat inadequate,' in the context of your professional life as well as personal life?'

On the other hand, some techniques did not need to be or could not be used. The use of silence was not utilized simply because the medium does not allow for it, as the recourse of asking about habits from an earlier time in a person's life was unrealistic since the medium (the World Wide Web) is too new to have had older habits about which to speak; the negative laddering technique could also not be implemented as the study did not have comparisons and, therefore, did not have the characteristics the respondents considered contrary to those cited. Finally, the revelation of a personal fact was avoided due to moral and ethical issues, despite the medium lending itself to such use since the interviewee and interviewee do not come into direct personal contact.

Lastly, as for the possible problems identified by Woodruff and Gardial (1996), the researcher dealt with these in the following way:

Repeated use of questions can cause an impression upon the interview subject that they are very obvious - in one of the first messages sent to each interviewee, the interviewer makes this possibility clear. The interviewer explains that it is part and parcel of the methodology of the interview, and this was reiterated several times during the interview process, as exemplified below: 
'As I explained in the last email, sometimes the questions may seem obvious, but this is all part of the research process...'

Interviewee becoming fatigued - as the interview was not carried out only one go in, the possibility of fatigue on the part of the interviewee was considered remote, since he or she could respond to the emails at their convenience.

\section{DATA ANALYSIS}

The laddering method contemplates data analysis as a four-step series: content analysis of the interviews and codification of identified elements; quantification of existing relationships between elements, resulting in the implication matrix; construction of a hierarchical value map; and, lastly, determination of dominant perceptual orientations (Copetti, 2005; Gengler \& Reynolds, 1995; Kaminski \& Prado, 2005; Leão \& Mello, 2001, 2002, 2003; Reynolds \& Gutman, 1988; ValetteFlorence \& Rapacchi, 1991).

\section{Content Analysis}

Content analysis was performed by dismembering rough data from the interviews in a representation of attribute concepts (concrete and abstract), consequences (functional and psychological) and values (instrumental and terminal). This was done through scanning, identifying the passages of the interviews that best represented the means-end theory. Next, from each phrase, a key sentence that best represented it was identified. From this point on, special care was taken to allocate phrases with the same meaning to single elements, as a way to limit their number.

\section{Table 1: Summary of Content Codes}

\begin{tabular}{|l|l|l|l|}
\hline Concrete attributes & Functional consequences & Psychological consequences & Instrumental value \\
\hline (01) Information & (11) Being well informed/up- & (19) Performing tasks & (27) Helpfulness \\
(02) Miscellaneous & to-date & (20) Performing non-task & \\
(03) Visual & (12) Optimizing time & activities & \\
presentation & (13) Saving money & (21) Contributing to & \\
(04) Search engine & (14) Researching & employment & \\
\cline { 1 - 3 } Abstract attributes & (15) Being convenient & (22) Having the common good & Terminal values \\
\cline { 1 - 3 } (05) Ease of use & (16) Facilitates saving data & in mind & (28) Fun/Enjoyment \\
(06) Quality & (17) Stimulating & (23) Qualifying professionally & (29) Belonging \\
(07) Speed & (18) Facilitates understanding & (24) Not being & (30) Security \\
(08) Being on-line & & excluded/discriminated & (31) Attachment \\
(09) Being local & & (25) Exercising citizenship & (32) Self-fulfillment \\
(10) Gratuitousness & & (26) Interacting with other & (33) Equality \\
& & people & \\
\hline
\end{tabular}

The next step was the identification of key elements. The number of elements that emerged was 109. This large amount of elements is predictable, due to the different ways people have of expressing themselves. Nevertheless, the use of all elements would considerably harm the analysis because the results would not generate effective main connections between attributes, consequences and values, establishing potentially weak relationships. Some indicate that it is paramount to identify how interviewees express, even in different terms, the same opinion regarding something in order to make the grouping of citations possible in more representative elements of meaning (Reynolds \& Gutman, 1988; Woodruff \& Gardial, 1996). Many citations did not form a strong element, or no strong element at all. In these cases they were discarded, as only the most important ones can collaborate in an effective way with the findings. 
Following this grouping, 33 elements ultimately emerged. Numbers representing attributes, consequences and values were used to codify them (according to Table 1). After the identification and codification of all elements, a numeric table was set up from the rough data representing all ladders per respondent. From this table, it was possible to perform an analysis of direct relationships, i.e. relationships between adjacent elements. On the other hand, it was also possible to perform an analysis of indirect relationships, referring to elements that, although related, have other elements between them. These relationships supported the construction of the implication matrix and of the hierarchical value map, to be presented in the next sections.

Specifically with regard to the elements related to value, it is worth highlighting that we took as a basis two previously developed scales: the RVS (Rokaech, 1973) and the LOV (Kahle, Beatty, \& Homer, 1986). Of the seven values identified, six fit into the scales, one having been discovered showing one of the possibilities and qualities of qualitative research (Merriam, 1998) - , following the theory of means-ends chains.

\section{The Implication Matrix}

The second step of the analysis, the construction of the implication matrix (Table 2), represents the number of times each element leads to another, that is, on a ladder which element precedes another (Reynolds \& Gutman, 1988). The number of relations was presented through numbers in a fractional form, where the direct relations appear to the left of the decimal point and the indirect relations to the right. 
Table 2: Implication Matrix

\begin{tabular}{|c|c|c|c|c|c|c|c|c|c|c|c|c|c|c|c|c|c|c|c|c|c|c|c|c|c|c|c|c|c|c|c|}
\hline$\tilde{m}$ & 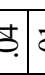 & b. & & ธิ & 8. & & & b. & ప) & 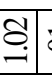 & ठढ. & & & & & & & б. & & & 훗. & & \begin{tabular}{|l|} 
\\
\end{tabular} & \begin{tabular}{|l|} 
\\
i \\
\end{tabular} & & & & & & & \\
\hline लె & 8. & 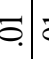 & के & & & |. & & & & & ָे & & & 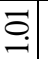 & & & & & 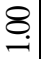 & - & & (ָ) & $\mid \vec{\sim}$ & & & 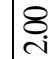 & & & & & \\
\hline$\vec{m}$ & $\vec{v}_{\mathrm{v}}$ & $\delta$ & & & 0 & ठढ. & & & $\begin{array}{l}\vec{c} \\
\dot{m} \\
\dot{m}\end{array}$ & & 8 & & & & & & & & & & $\underset{\text { ले }}{8}$ & & & & & & & & & & \\
\hline లి & se & 8 & & $\vec{c}$ & ธิ & 8. & $\%$ & ㅇ. & c. & 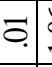 & 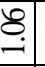 & 岁 & & ฮิ. & $\bar{c}$ & 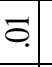 & & & ت્. & \begin{tabular}{|c|c|} 
\\
$\dot{m}$
\end{tabular} & 8.8 & : & के & & & 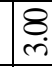 & & & & 8 & \\
\hline N & $=$ & . & t. & & 8. & छ! & 8 & $\begin{array}{l} \\
\\
\end{array}$ & $\overrightarrow{\sigma_{-}}$ & & $\begin{array}{l} \\
0 \\
6 \\
\end{array}$ & 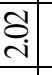 & & & & & & & & 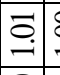 & 8 & 5 & \begin{tabular}{|c|}
\multirow{2}{*}{} \\
\end{tabular} & \begin{tabular}{|l|l}
\multirow{i}{*}{} \\
\end{tabular} & $\begin{array}{c}8 \\
\end{array}$ & $\underset{-8}{8}$ & & & $\begin{array}{c} \\
\text { i } \\
\end{array}$ & & \\
\hline$\stackrel{\sim}{\sim}$ & L్. & ְ. & $\vec{G}_{-\rightarrow}$ & . & 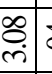 & ठ & o. & $\begin{array}{l} \\
\\
\end{array}$ & ช. & & . & \begin{tabular}{l|l}
\multirow{2}{*}{} \\
$\infty$ \\
$\infty$
\end{tabular} & $\begin{array}{l} \\
\text { ले }\end{array}$ & & ठढ. & $\underset{-}{8}$ & $\begin{array}{l} \\
\end{array}$ & & & \begin{tabular}{|l|}
8 \\
\\
\end{tabular} & 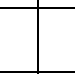 & & & & 8 & & & & & & \\
\hline$\hat{\mathrm{v}}$ & 8 & है. & & के & ठ. & 8. & & 8 & c. & & | & & & б. & & c. & & & & & $\underset{9}{8}$ & & & 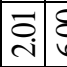 & : & & & & & & \\
\hline ¿ & 8 & c. & $\overrightarrow{\vec{\sigma}}$ & & $\begin{array}{c}\mathrm{C} \\
\mathrm{i}\end{array}$ & త্ড & & : & $\sigma$ & & t. & $\underset{\substack{8\\
}}{ }$ & & & & & & & & & & & 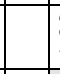 & $\underset{-8}{8}$ & & & & & & & \\
\hline ㅁำ & Lి & $\underset{-}{0}$ & t. & & $\bar{\sigma}$ & : & ప. & & $\begin{array}{c}\overrightarrow{1} \\
\\
\end{array}$ & & \begin{tabular}{|l|} 
\\
$\infty$ \\
$\infty$ \\
\end{tabular} & & & & & & 8 & & & & 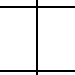 & & $\underset{\mid}{8}$ & & & & & & & & \\
\hline$\dot{\Delta}$ & 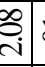 & है. & & & o. & & & 8 & c. & 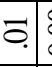 & $\begin{array}{l} \\
\\
\end{array}$ & 8 & & & & & & & & & 8 & : & & & & & & & & & \\
\hline$\approx$ & s. & & & $\overline{0}$ & \begin{tabular}{l|l}
\multirow{2}{*}{} \\
\end{tabular} & б. & 8 & & 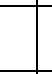 & $\varepsilon$ & 8 & & & & & & & . & & & & & \begin{tabular}{|c|}
8 \\
\end{tabular} & & & & & & & & \\
\hline$\approx$ & סे & & & ธิ) & 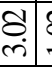 & ב⿱ & & 它 & 8 & $\begin{array}{l}8 \\
\dot{m}\end{array} \mid$ & 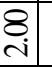 & & & б. & & 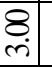 & & $\underset{-1}{8}$ & & & & & 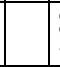 & $\underset{-1}{8}$ & & & & & & & \\
\hline$\vec{\nabla}$ & 8. & . & t. & & 8 & a & o. & 8. & 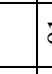 & 0 & $\begin{array}{l} \\
0 \\
6\end{array}$ & ㅎ. & & & & & & & \begin{tabular}{|c|}
8 \\
\end{tabular} & \begin{tabular}{|c|}
8 \\
\end{tabular} & & \begin{tabular}{|l|}
$\overrightarrow{0}$ \\
ம. \\
\end{tabular} & \begin{tabular}{|c|}
\multirow{2}{*}{} \\
in
\end{tabular} & & & & & & & & \\
\hline จิ & S. & & ช. & & d: & |- & 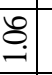 & 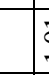 & $\vec{\sigma}$ & & $\vec{\sigma}$ & $\begin{array}{l}\overrightarrow{0} \\
0 \\
0\end{array}$ & $\begin{array}{l} \\
\\
\end{array}$ & & & & & & & & & & & & & & & & & & \\
\hline 9 & (2) & . & $\overline{0}$ & L. & $\begin{array}{c}\mathrm{i} \\
\text { ì }\end{array}$ & ㄴ. & d. & 8 & & & $\begin{array}{l}8 \\
\dot{m}\end{array}$ & $\underset{8}{8}$ & & $\begin{array}{l}8 \\
+\end{array}$ & o. & 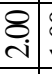 & $\underset{8}{8}$ & 8 & & & & & & & & & & & & & \\
\hline$\stackrel{\infty}{\sim}$ & 8. & & 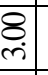 & & $\begin{array}{l}8 \\
\text { ले }\end{array}$ & 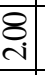 & & o. & & & & & & & & & & & & & & & & & & & & & & & \\
\hline 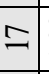 & 8 & & $\begin{array}{l}8 \\
\\
\end{array}$ & & 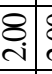 & 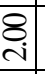 & 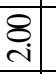 & & & & . & & & & & & & & & & & & & & & & & & & & \\
\hline 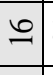 & . & . & & $\begin{array}{c}\tilde{i} \\
\stackrel{i}{*}\end{array}$ & 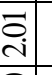 & & & \begin{tabular}{l|}
$\overrightarrow{5}$ \\
+ \\
\end{tabular} & & & & & & $\underset{i}{8}$ & : & & & & & & & & & & & & & & & & \\
\hline$\stackrel{2}{\sim}$ & 8 & 0 & & 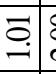 & 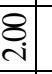 & & $\begin{array}{c}8 \\
\end{array}$ & $\begin{array}{l} \\
\\
+ \\
+\end{array}$ & & & & & & & & & & & & & & & & & & & & & & & \\
\hline 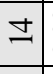 & ت. & & & $\begin{array}{ll}\dot{\theta} \\
\dot{m}\end{array}$ & $\begin{array}{l}8 \\
\\
1\end{array}$ & & & & & & & & & & $\underset{8}{8}$ & & & & & & & & & & & & & & & & \\
\hline 9 & b. & 8 & ธ. & 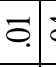 & t. & ๑. & 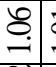 & | & & ¿্ণ & 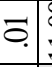 & $\begin{array}{l}8 \\
\\
\end{array}$ & & & & & & & & & & & & & & & & & & & \\
\hline$\simeq$ & \begin{tabular}{l|} 
\\
i \\
\end{tabular} & $\begin{array}{l} \\
\\
\text { ले }\end{array}$ & 8. & \begin{tabular}{c|c} 
\\
- \\
\end{tabular} & 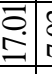 & 管. & 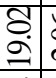 & 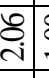 & $\begin{array}{l}8 \\
- \\
\end{array}$ & & $\begin{array}{l}8 \\
\dot{m} \\
\end{array}$ & & & & $\begin{array}{l} \\
\\
\end{array}$ & $\underset{-}{8}$ & & & & & & & & & & & & & & & \\
\hline$\exists$ & 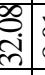 & \begin{tabular}{l|}
$\vec{b}$ \\
$\infty$ \\
\end{tabular} & כ) & 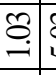 & 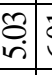 & $\vec{~}$ & $\begin{array}{c}\tilde{\sigma} \\
\tilde{m}\end{array}$ & $\begin{array}{l}0 \\
\tilde{+} \\
\dot{+}\end{array}$ & $\begin{array}{c}8 \\
\text { ì }\end{array}$ & 8 & & & & $\overrightarrow{\mathrm{d}}$ & $\vec{c}$ & 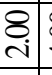 & $\begin{array}{l}8 \\
+ \\
\end{array}$ & & & & & & & & & & & & & & \\
\hline 으 & 8 & & & & & & & & & & & & & & & & & & & & & & & & & & & & & & \\
\hline$\sigma$ & $\underset{\text { ¿ }}{\mathbb{i}}$ & & & & & & & & & & & & & & & & & & & & & & & & & & & & & & \\
\hline$\infty$ & & (8) & & & & & & & & & & & & & & & & & & & & & & & & & & & & & \\
\hline$\wedge$ & $\begin{array}{l}\overrightarrow{3} \\
\text { ले } \\
\end{array}$ & & $\begin{array}{l} \\
\\
\end{array}$ & & & 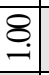 & & 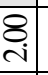 & & & & & & & & & & & & & & & & & & & & & & & \\
\hline 0 & $\begin{array}{l}8 \\
15 \\
\end{array}$ & & $\begin{array}{c} \\
\text { ल. }\end{array}$ & & & & & ¿ & 8 & & & & & & & & & & & & & & & & & & & & & & \\
\hline L & \begin{tabular}{l|l}
8 \\
\\
\end{tabular} & 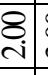 & 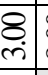 & $\begin{array}{l}8 \\
\infty \\
\infty\end{array}$ & & $\begin{array}{l}8 \\
+ \\
+\end{array}$ & 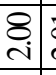 & ت્خ & & & & & & & & & & & & & & & & & & & & & & & \\
\hline$\nabla$ & & & & & & & & & & & & & & & & & & & & & & & & & & & & & & & \\
\hline$m$ & & & & & & & & & & & & & & & & & & & & & & & & & & & & & & & \\
\hline$\sim$ & & & & & & & & & & & & & & & & & & & & & & & & & & & & & & & \\
\hline-1 & & 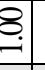 & & & & & & & & & & & & & & & & & & & & & & & & & & & & & \\
\hline & -10 & 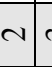 & $m$. & $\nabla$ & n & 0 & $\wedge$ & $\infty$ & बा & 의: & $=$ & $\approx$ & 9 & $\nabla$ & $\stackrel{2}{2}$ & 9 & $\triangle$ & $\underset{\sim}{-\infty}$ & 9 & নি: & $\bar{\approx} \approx$ & $\tilde{\nabla}$ & $\bar{A}$ & Lั & $\stackrel{\overbrace{}}{ }$ & $\stackrel{\sim}{\infty}$ & 2 & లి: & $\vec{m} \delta$ & $\tilde{m}$ & $m$ \\
\hline
\end{tabular}




\section{Constructing the Hierarchical Value Map}

In the third step of the analysis, the construction of the hierarchical value map, the chains are rebuilt from the data aggregated in the implication matrix. The purpose of mapping these hierarchical relations is to interconnect all significant chains in a manner that is easy to read and interpret (Reynolds \& Gutman, 1988). To avoid confusion, from this point on, ladders will be understood as the individual elicited sequences and chains as the sequences of elements that emerged from the implication matrix (Reynolds \& Gutman, 1988; Valette-Florence \& Rapacchi, 1991). To build the map, a typical approach is to identify all existing relations from a cutoff level (usually between 3 and 5). Such criteria can apply to all relations, both direct and indirect, or only the direct ones. Thus, many cells from the implication matrix will not be used in the construction of the map, due to their low score, which is understood as a weak relation. However, the correct cutoff level decision should make the map cover at least two thirds of all existing relations in the implication matrix. There are elements that, even though their relations are not considered in the map construction, can still appear related in the same chain on the map (Reynolds \& Gutman, 1988; Valette-Florence \& Rapacchi, 1991). In this sense, the large amount of elements (33), mostly producing indirect relations amongst themselves, left no doubt that all relations, direct or indirect, should be considered, owing to risk of losing important data. Considering the average number of relations per cell in the implication matrix, a decision was made to consider the number three (3) as the most adequate for the cutoff level because it would include a representative number of relations. As has already been mentioned, a number lower than this is not recommended by the literature and above it would restrict the analysis to few relations as it would exclude a large amount of the cells from the map, which would tend to weaken it.

A flexible criterion was needed: by considering the cutoff level as 3 , a few weak relationships between terminal values were found. Since, conceptually, one terminal value does not lead to another - rather instrumental to terminal - this relation was not considered. In the end, $88,4 \%$ of all the existing relations were represented in the hierarchical value map (see Figure 2).

To build the map, it is necessary to keep in mind all the types of relations possible between the elements, of which there are five (Reynolds \& Gutman, 1988): A-D - elements mapped as adjacent and have a high number of direct relations (the most common type, typically the pattern used in the map construction); N-D - elements mapped as nonadjacent and have a high number of direct relations (elements characterized by many direct relations, although plotted separately because another element between them exists, with strong direct relations with both); A-I - adjacent elements that have a high number of indirect relations but a low number of direct relations (elements that have strong indirect relations are placed in a adjacent way because of the lack of an element with strong direct relations with them); $\mathbf{N}-\mathbf{I}$ - nonadjacent elements that have a low, nonzero number of direct relations but a high number of indirect relations (in addition, the A-D is easily characterized because it presents elements with many more indirect relations and, therefore, placed separately); $\mathbf{N}-\mathbf{O}$ nonadjacent elements that have a low (or zero) number of indirect relations (although it is a type of relation where there can be few or no relations between the two elements, these can be placed in a nonadjacent form owing to the sequence of relations).

For the process of map construction, Reynolds and Gutman (1988) explain that the chains must be built, starting from the first row of the matrix in search of the first cell with a number of relations equal or superior to the cutoff level. When this cell is found, one would move down to the row of the element of said cell and then repeat the process again and again. From this point onward, what follows is a brief account of how the map was built. 
Figure 2: Hierarchical Value Map

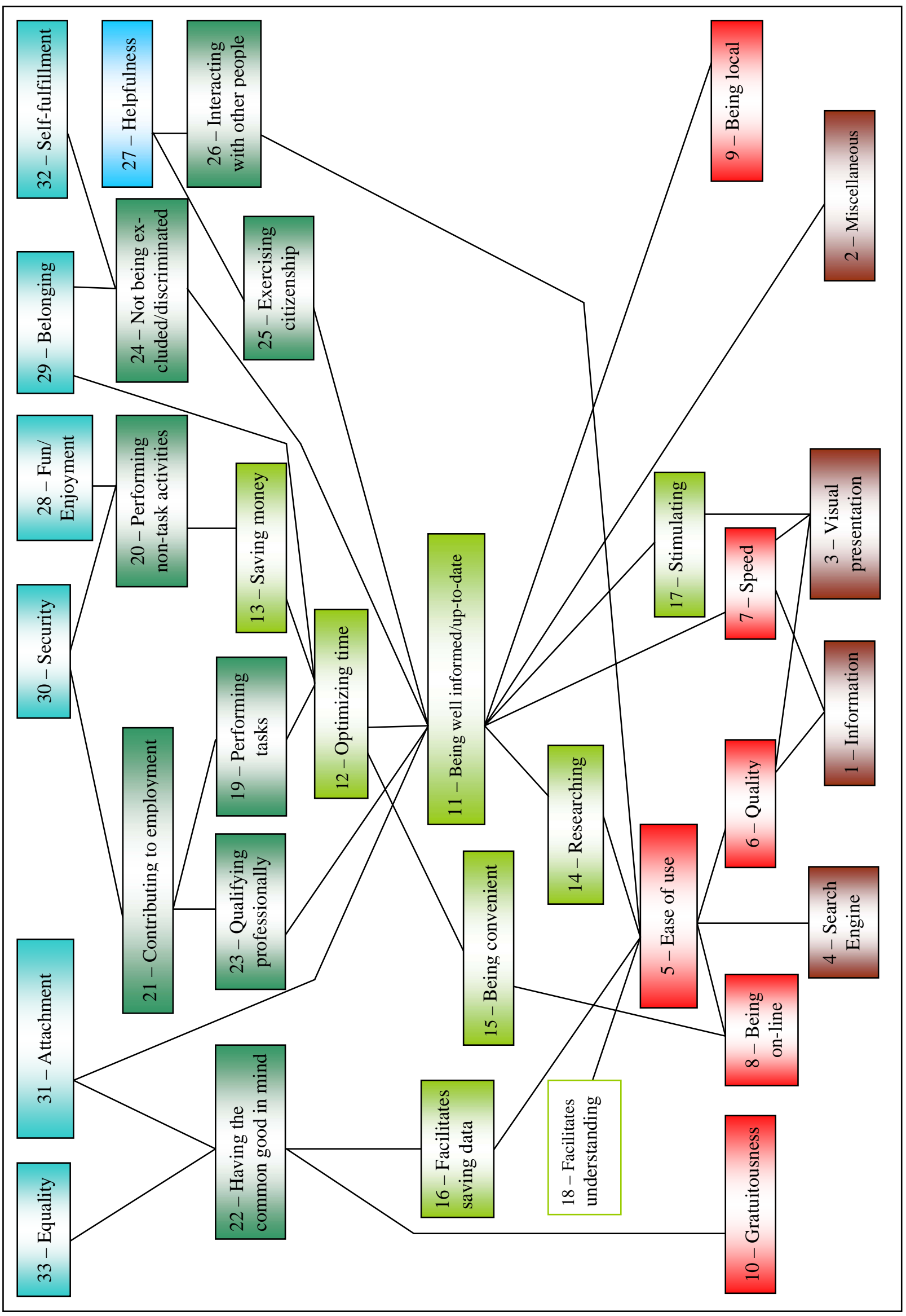


Analyzing the implication matrix from the first row ${ }^{(1)}$, the first element found with a valid number of relations was 5 . However, the interval between 5 and 10 refers to a same level (abstract attributes) which will be the unit of analysis from now on - in which three elements with valid relations $(5,6$ and 7) were found. Verifying the row that refers to each of the elements, the following were found: in row five, the next valid element was 11; in row six, was 5 (followed by 11); in row seven, the next element was also 11. These relations point to the beginning of two chains: 1-6-5-11 and 1-7-11.

The analysis will start with the first chain mentioned. The first important observation is that, although the 1-5 relation has eight direct and no indirect connections, these two elements appear separately in the chain, due to the fact that element 6 fits perfectly between the two. It is, therefore, an $\mathrm{N}-\mathrm{D}$ relation, which happened again under many other circumstances. The next step was to jump to row eleven, where element 12 was found. Moving on to row twelve, element 13 was found and, continuing this process, the chain arrived at element 28 (a value). The first chain was ready: 1-6-5-1112-13-28. However, the increase of elements 14 before 11 and 20 before 28 occurred, producing the final form: 1-6-5-14-11-12-13-20-28. The addition of these two elements happened after they were identified when returning to the original row in search of lost elements during the first plotting. As to the inclusion of element 14, while evaluating the fourteenth row, it was realized that it is related to consequences 11 and 19. This indicated the need to plot it in this chain, due to the presence of element 11. Although the 5-11 relation is preferably a direct one, presenting five relations of this type, it also has three indirect relations that pointed to the possibility of it becoming an N-D relation. As to the 1328 relation, although it presented three direct relations and none indirect, it was realized that element 20 relates directly with element 28 , at the end of the chain, and that the 20-28 relation was much stronger than the 13-28, with seven direct relations, which justified its inclusion in the chain. The 1320 relation, although not foreseen between the valid relations, seemed to make sense within this context, and the 13-28 relation was characterized as an N-D one. It was also realized that element 20 guided to a second value, the element 30 . In this way, a new chain with the same base as the previous one was created with the 20-30 relation (1-6-5-14-11-12-13-20-30).

Returning to the second chain which had started from the first row (1-7-11) and following the same procedures used to generate the previous chains, the elements found after the 1-7-11 sequence were the same as those from element 11 , which gave birth to two more chains (1-7-11-12-13-20-28 and 1-711-12-13-20-30). It is curious that four chains begin in the same concrete attribute (1), go through different abstract attributes (6, 5 and 14, on one side, and 7 on the other), follow the same path from consequence 11 and again split towards two values (28 and 30), which is better understood from the illustration below:

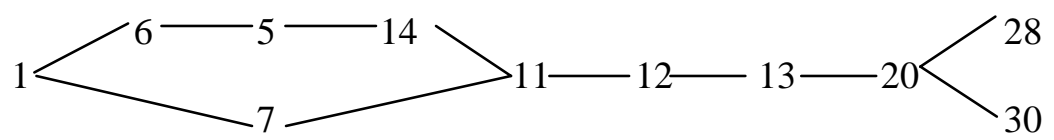

The next step was to return to the first row and identify non-plotted elements in the four first chains with a valid number of relations. The first of the elements considered to be invalid was 18, indicating an indirect relation with 1 . Going down to the fifth row, element 5 was identified, also related to 18, in a direct way, which indicated the formation of another chain: 1-6-5-18. However, element 18 did not generate any other, thus concluding this chain - the only one that did not lead to a value and, therefore, made invalid. For this reason, element 18 appears without a background color on the map, differentiating it from the others.

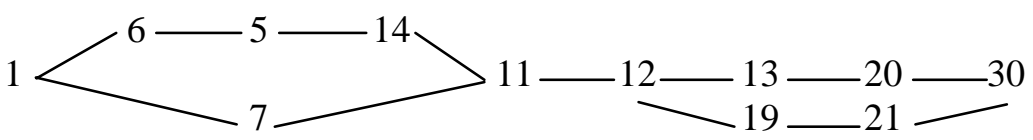


Returning once again to the top of the matrix, the next valid element was 19. Descending to the nineteenth row, this element led to 21 which, in turn, led to 30, both elements present in the first row as indirect relations to 1 . Between element 1 and the sequence 19-21-30, elements 5, 6 and 7 presented valid indirect relations; element 12 presented a direct relation to 19; element 11 presented an indirect relation to 30; and 14 a direct one to 19, as anticipated. With this, two new chains, taking advantage of part of the two previous sequences that ended with value 30, were originated, taking a short cut from the element 12 and returning to element 30 , as is clearly illustrated above:

Looping back to the first row of the matrix, the next element is 22, which leads to the values 31 and 33. Beginning by the 22-31 relation, aiming to identify the chain formed from element 1 , only elements 6 and 5 demonstrated a relation to 22, indicating the origin of the chain. However, going to the fifth line, another element before 22 was perceived (16), in the shape of a direct relation. While verifying the sixteenth row, the direct relation between 16 and 22 was confirmed, which concluded the new chain: 1-6-5-16-22-31. Advancing to the 22-33 relation, it was noticed that it came from the previous chain, excluding element 31. Elements 1 and 5 also relate to value 33, while relations 6-33 and 16-33 can be configured as an N-O type. The following illustration presents these two chains:<smiles>IS[131I]S[131I-]</smiles>

This procedure was repeated until all possible relations from the first row were identified. The same analysis was undertaken for the second row and so forth. It is important to point out that element 1 , amongst all, is the richest provider of relations emanating from it, which facilitated new chain identification from the second row.

Table 3: Summary of the Direct (XX) and Indirect (YY) Relations of Each Element (XX.YY)

\begin{tabular}{|c|c|c|c|c|c|c|c|c|}
\hline Code & From & Coming to & Code & From & Coming to & Code & From & Coming to \\
\hline 1 & 72.115 & 1.00 & 12 & 42.14 & 58.31 & 23 & 8.03 & 15.15 \\
\hline 2 & 18.25 & 0.00 & 13 & 6.00 & 15.21 & 24 & 9.03 & 14.14 \\
\hline 3 & 19.25 & 0.00 & 14 & 8.07 & 11.06 & 25 & 7.01 & 14.12 \\
\hline 4 & 16.28 & 0.00 & 15 & 6.04 & 9.04 & 26 & 8.01 & 10.10 \\
\hline 5 & 48.53 & 29.01 & 16 & 9.02 & 10.06 & 27 & 1.00 & 10.20 \\
\hline 6 & 27.31 & 11.00 & 17 & 7.00 & 12.00 & 28 & 6.00 & 24.47 \\
\hline 7 & 29.44 & 9.01 & 18 & 3.01 & 8.04 & 29 & 0.00 & 20.37 \\
\hline 8 & 26.41 & 2.00 & 19 & 5.01 & 22.31 & 30 & 0.00 & 21.42 \\
\hline 9 & 11.11 & 2.00 & 20 & 12.03 & 17.25 & 31 & 2.00 & 15.15 \\
\hline 10 & 7.03 & 1.00 & 21 & 7.00 & 17.33 & 32 & 1.00 & 10.14 \\
\hline 11 & 58.23 & 72.25 & 22 & 13.02 & 19.10 & 33 & 0.00 & 11.17 \\
\hline
\end{tabular}

After the map construction, it is desirable to look at all elements in terms of the numbers of direct and indirect relations they have with other elements, both in terms of other elements leading into them and in terms of their connections to higher order elements. Table 3 presents the sums of the direct and indirect relations for each element. Such a table also provides easy identification of the most important elements in each level.

As for the attributes, information is, by far, the most important of all (72 direct relations and 115 indirect relations generated from that). Within the abstract attributes, easy usage is the most important with 48 direct relations and 53 indirect relations generated from it. It is important to mention that the table, like the map, clearly shows that the concrete attributes easy usage, quality and speed, are in an intermediate level of relation, as they derive directly from concrete attributes and bear the consequences. On the other hand, the remaining abstract attributes (being on-line, being local and gratuitousness) do not derive from the concrete ones, being the base of the chains where they are 
inserted. Finally, it is important to highlight that the attributes being local and gratuitousness are the weakest of those identified.

On the consequence level, the analysis becomes related to the two columns, since they are linking elements between attributes and values. Among the functional attributes, being well informed/up to date ends up being the most important, followed by the optimizing time as much as in the relationships stemming from them as in those leading to them, characterizing them as the main elements of linkage. On the map, this function becomes clear, especially in relation to element 11 (being well informed/up to date), put in the center. Element 18 is notwithstanding, outside the analysis of the map, the weakest functional attribute is being convenient. In terms of psychological attributes, performing tasks and performing non-task activities, practically with the same amount of relationships, are the most important ones. Interacting with other people, followed by exercising citizenship, are the weakest elements of this level.

With respect to values, the important relations will be those coming towards it, since these are on top of the map. The instrumental value, helpfulness, could, conceptually, be taking terminal values, which does not happen. Perhaps it is at this point its lack of contribution to the cognitive map, with merely 10 direct relationships and 20 indirect relationships leading into it. As far as the terminal values are concerned, a peculiarity is noticed: three elements are far more significant than the other three. Fun/Enjoyment appear among the highest values among the newspaper's users, with 71 relationships leading to it, security (63 relationships) and belonging (57 relationships) are far ahead of the other three: attachment (30 relationships), equality (28 relationships) and self fulfillment (24 relations).

\section{Determining Dominant Perceptual Orientations}

Once the hierarchical value map is built, the existing paths from the base to the top are considered as representative chains of perceptual orientation. To determine which of these chains are dominant, i.e., which are the most important, considering the relations from its base (A) to its top (V), to comprehend which contributed most to the results, the total number of existing direct and indirect relations in each possible chain of the map needs to be counted (Reynolds \& Gutman, 1988; Valette-Florence \& Rapacchi, 1991).

In all, the resulting map reached 100 chains. To identify the dominant chains, theoretically, one needs to determine the largest sums of the relations. However, two aspects are important in this matter: 1) once all the relation sums are ranked, what number could be considered as representative of relevance, i.e. which number would be the cutoff level?; and 2) by looking at the map and the 100 new matrices (one for each perceptual orientation), it can be seen that the chains vary greatly in number of composing elements (from three to nine), which leads to a conclusion that chains with a greater number of elements tend to have greater relation sums when compared to chains with a lower number of elements, which does not necessarily mean, that they are more important. Even so, the analysis should be relative and not absolute. To solve such problems, two decisions were made: 1) regarding the cutoff level, the solution identified was to find the mean of the number of relations (the sum of direct and indirect) of all chains and consider it as the cutoff level, that is, consider as dominant those chains that, at least, equaled the mean of all chains; 2) this mean was calculated for each group of chains with an equal number of relations amongst themselves, which prevented the fallacy of determining the largest chains as dominant.

To elucidate, an example of how this determination occurred is presented. Among the 100 chains, 23 were formed by 6 elements. Adding the relations of each of these chains and calculating their mean, one arrives at the number 65.45. Since relations are whole numbers, the dominant chains were considered to be those with a number of relationships equal or superior to 66 . Of the 23 , only 9 chains were on this platform.

Continuing with this procedure for all other six groups of chains by number of elements, 35 dominant chains were identified among the 100 . However, from these, only 19 perceptual orientations 
were configured (see Table 4). This can be explained due to the fact that a same relationship from the base to the top (a perceptual orientation) can be composed by more than one chain, following different paths (especially through consequences) relating a same attribute to a same value.

Table 4: Dominant Perceptual Orientations

\begin{tabular}{|c|c|c|}
\hline Information - Fun/Enjoyment & Information - Security & Information - Belonging \\
Miscellaneous - Fun/Enjoyment & Miscellaneous - Security & Miscellaneous - Belonging \\
Visual presentation.- Fun/Enjoyment & Being on-line - Security & Being on-line - Belonging \\
Search engine - Fun/Enjoyment & Information - Helpfulness & Search engine - Belonging \\
Being on-line - Fun/Enjoyment & Miscellaneous - Helpfulness & Information - Attachment \\
Information - Self-fulfillment & Search engine - Helpfulness & Varieties - Attachment \\
& & Being local - Attachment \\
\hline
\end{tabular}

\section{CONCLUSION}

One aspect became very clear from this research: the cognitive map of users of the on-line newspaper researched points to many directions. This is evidenced by the large number of elements, as well as by the complexity of the users' understanding of the relationships between service attributes and the benefits that can be extracted from it to values, generating extensive means-end chains, something which is rather unusual if we observe some of the main studies of the same nature already published (e.g. Gengler \& Reynolds, 1995; Reynolds \& Norvell, 2001).

Fun/Enjoyment and belonging, two of the three most important values, are the ones that have the largest quantity of attributes ( 5 and 4 respectively) and therefore generate a greater quantity of perception orientations. Another quite important value, security, generates orientations with 3 only attributes; however, it is the one that is represented in the highest number of chains. That seems to indicate that the individual objectives of individual tastes and needs tend to need a greater variety of services. However, they are utilized in a similar manner (which is clearly evidenced by the number of chains). In contrast, security can be achieved with less service, but with greater possibilities of use. This analysis seems to indicate that, while the two first values demand a higher quantity of services and information, the latter requires more in-depth and specific services and information.

The remaining values seem to ratify this line of thinking: while attachment, related to line 1 , is in 3 orientations of perception, self-fulfillment, related to the same line as security, builds only one. Of the more socially-oriented values, helpfulness points to the line of thinking of the first value group, building 3 orientations of perception. Equality, however, has not appeared within the dominant orientations.

Consequently, it seen that the values related to personal objectives are the most important. Fun/Enjoyment, security, and belonging show a very peculiar trend among the users. In general terms, the users show the will to seek success in life, which results in security, but they also know they need enjoyment and the feeling of not being alone. How they are going to achieve this (through an online newspaper), as was clearly shown, will basically be derived from the knowledge that its information provides, used in various ways: as a way of planning leisure time, to gain professional qualification or be accepted in society. In other words, the user seems to clearly view the online newspaper as a means of reaping personal gains in way that is more dynamic than others.

A very important observation in the behavior of this consumer is that, despite common sense pointing towards an increasingly isolated and selfish mankind, the values identified show exactly the opposite: mankind primarily interested in interacting with others, which he finds on the Internet, indirectly, or the resources required to make possible realize such desires in daily life. In contrast, it also shows a mankind that - even not prioritizing a social life - shows a clear preoccupation with what is happening around him and how he can interact with it. 
Aside from these findings, it is important to highlight two important contributions present in the research. The first is of a methodological nature. The means in which the laddering was used here (online, through e-mails) is not the usual one nor is it suggested by literature. Therefore, by realizing such an adaptation, we contribute to a new possibility of its application. On the other hand, from a theoretical standpoint, we discover a value unforeseen by the literature (Attachment), which is one of the main contributions of the qualitative research. Considering the socio-cultural changes which our societies have been through, a better understanding of the values not foreseen decades ago can also contribute to the understanding of the very changes in the consumers themselves.

There is much more work to be done in thinking about how the conclusions presented here can be applied in the real world. Future research for managerial practices is warranted in areas such as segmentation, satisfaction measuring and customer value reevaluation, aside from copy tests. Academic research could benefit from a broader understanding and use of the means-end theory and laddering on the Web. In this sense, the growth of electronic commerce suggests that customer value can be used to understand on-line consumer behavior.

\section{NOTE}

\footnotetext{
${ }^{1}$ From this point on, the numbers regarding the implication matrix rows will be written in text form, while the elements will be presented numerically.
}

\section{REFERENCES}

Copetti, C. L. P. (2005). Valor para o cliente: análise de congruência sob a perspectiva do consumidor final e da comunicação. Unpublished master’s thesis. São Leolpodo: Unisinos.

Dibley, A., \& Baker, S. (2001). Uncovering the links between brand choice and personal values among young British and Spanish girls. Journal of Consumer Behavior, 1(1), 77-93.

Gengler, C., Mulvey, M. S., \& Oglethorpe, J. E. (1999). A means-end analysis of mother's infant feeding choices. Journal of Public Policy \& Marketing, 18(2), 172-188.

Gengler, C., \& Reynolds, T. J. (1995). Consumer understanding and advertising strategy: analysis and strategic translation of laddering data. Journal of Advertising Research, 35(4), 19-33.

Grunert, K. G., Sorensen, E., Johansen, L. B., \& Nielsen, N. A. (1995). Analysing food choice from a means-end perspective. European Advances in Consumer Research, 2, pp. 366-71.

Gutman, J. (1981). A means-end model for facilitating analysis of product markets based on consumer judgement. Advances in Consumer Research, 8, pp. 116-21.

Gutman, J. (1982). A means-end chain model based on consumer categorization processes. Journal of Marketing, 46(2), 60-72.

Hunt, S. D. (1991). Modern marketing theory. Cincinati: South-Western Publishing Company.

Kahle, L. R., Beatty, S. E. \& Homer, P. (1986). Alternative measurement approaches to consumer values: the list of values (LOV) and values and life style (VALS). Journal of consumer research, 13(3), 405-409.

Kamakura, W. A., \& Mazzon, J. A. (1991). Value segmentation: A model for the measurement of values and value systems. Journal of Consumer Research, 18(2), 208-219. 
Kamakura, W. A., \& Novak, T. P. (1992). Value-system segmentation: exploring the meaning of LOV. Journal of Consumer Research, 19(1), 119-133.

Kaminski, S. R., \& Prado, P. H. M. (2005). O consumo de música segundo modelo de cadeias de meios-fim: uma aplicação da association pattern technique (APT). Anais do Encontro Nacional dos Programas de Pós-Graduação em Administração, Brasília, DF, Brasil, 29.

Leão, A. L. M. S., \& Mello, S. C. B. (2001). Mensurando customer value através do método laddering: uma proposta de aplicação da técnica para o ambiente virtual. Anais do Encontro Nacional dos Programas de Pós-Graduação em Administração, Campinas, SP, Brasil, 25.

Leão, A. L. M. S., \& Mello, S. C. B. (2002). Conhecendo o valor do cliente virtual: uma análise utilizando a teoria de cadeias de meios-fim. Anais do Encontro Nacional dos Programas de PósGraduação em Administração, Salvador, BA, Brasil, 26.

Leão, A. L. M. S., \& Mello, S. C. B. (2003, julho/setembro). Conhecendo o 'valor do cliente' de um jornal on-line. Revista de Administração de Empresas, 43(3), 22-35.

Lin, C. F. (2002). Attribute-consequence-value linkages: a new technique for understanding customers' product knowledge. Journal of Targeting, Measurement and Analysis for Marketing, 10(4), 339-52.

Mason, R. (1995). Measuring the demand for status goods: an evaluation of means-end chains and laddering. European Advances in Consumer Research, 2, pp. 78-81.

Merriam, S. B. (1998). Qualitative research and case study applications in education: revised and expanded from case study research in education. San Francisco: Jossey-Bass.

Mulvey, M. S., Olson, J. C., Celsi, R. L., \& Walker, B. A. (1994). Exploring the relationships between means-end knowledge and involvement. Advances in Consumer Research, 21, 51-7.

Olver, J. M., \& Mooradian, T. A. (2003). Personality traits and personal values: a conceptual and empirical integration. Personality and Individual Differences, 35(1), 109-125.

Perkins, W. S., \& Reynolds, T. J. (1988). The explanatory power of values in judgements: Validation of the means-end perspective. Advances in Consumer Research, 15, pp. 122-26.

Peter, J. P., \& Olson, J. C. (1999). Consumer behavior and marketing strategy (5th ed.). Boston: Irwin McGraw-Hill.

Prakash, V. (1986). Segmentation of women's market based on personal values and the means-end model: A framework for advertising strategy. Advances in Consumer Research, 13, pp. 215-20.

Reynolds, T. J., \& Gutman, J. (1984). Advertising is image management. Journal of Advertising Research, 24(1), 27-36.

Reynolds, T. J., \& Gutman, J. (1988). Laddering theory, method, analysis, and interpretation. Journal of Advertising Research, 28(1), 11-31.

Reynolds, T. J., \& Norvell, J. (2001). Fund-raising strategy: tapping into philanthropic value orientations. In J. R. Thomas \& J. Olson (Eds.). Understanding consumer decision making. Londod: Lawrence Erlbaum Associates, Publishers.

Reynolds, T. J., \& Perkins, W. S. (1987). Cognitive differentiation analysis: a new methodology for assessing the validity of means-end hierarchies. Advances in Consumer Research, 14, pp. 109-13.

Reynolds, T. J., \& Whitlark, D. B. (1995). Applying laddering data to communications strategy and advertising practice. Journal of Advertising Research, 35(4), 9-17.

Rokeach, M. (1968). Beliefs, attitudes, and values. San Francisco: Jossey Bass.

Rokeach, M. (1973). The nature of human values. New York: The Free Press. 
Rokeach, M. (1979). Understanding human values. New York: The Free Press.

Serralvo, F. A., \& Ignácio, C. P. (2005). O processo de escolha de marcas no mercado de produtos alimentícios. Anais do Encontro Nacional dos Programas de Pós-Graduação em Administração, Brasília, DF, Brasil, 29.

Valette-Florence, P., \& Rapacchi, B. (1991). Improvements in means-end chains analysis: using graph theory and correspondence analysis. Journal of Advertising Research, 31(1), 31, 30-45.

Veludo-de-Oliveira, T. M., \& Ikeda, A. A. (2004). Student value in marketing education. Proceedings Summer Marketing Educators' Conference - Enhancing Knowledge Development in Marketing, Boston, Massachusetts.

Vriens, M., \& Hofstede, F. T. (2000). Linking attributes, benefits, and consumer values. Marketing Research, 12(3), 4-10.

Walker, B. A., \& Olson, J. C. (1991). Means-end chains: connecting products with self. Journal of Business Research, 22(2), 111-118.

Woodruff, R. B., Schumann, D. W., \& Gardial, S. F. (1993, Summer/Fall). Understanding value and satisfaction from the customer's point of view. Survey of Business, 29(1), 33-40.

Woodruff, R. B., \& Gardial, S. F. (1996). Know your customer: new approaches to understanding customer value and satisfaction. Malden: Blackwell Business.

Woodruff, R. B. (1997). Customer value: the next source for competitive advantage. Journal of the Academy of Marketing Science, 25(2), 139-153. 